\title{
Az adalimumab hatékonysága és biztonságossága hagyományos kezelésre refrakter colitis ulcerosában
}

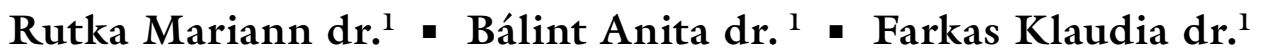 \\ Palatka Károly dr. ${ }^{2}$ - Lakner Lilla dr. ${ }^{3}$ - Miheller Pál $\mathrm{dr}^{4}{ }^{4}$ - Rácz István $\mathrm{dr} .{ }^{5}$ \\ Hegede Gábor dr. ${ }^{6}$ - Vincze Áron dr. ${ }^{7}$ - Horváth Gábor dr. ${ }^{8}$ \\ Szabó Andrea dr. ${ }^{5}$ - Nagy Ferenc dr. ${ }^{1}$. Szepes Zoltán dr. ${ }^{1}$ \\ Gábor Zoltán dr. ${ }^{8}$ - Zsigmond Ferenc dr. ${ }^{9}$ - Zsóri Ágnes dr. ${ }^{10}$ \\ Juhász Márk dr. ${ }^{4}$ - Csontos Ágnes dr. ${ }^{4}$ - Szücs Mónika dr. ${ }^{11}$ \\ Bor Renáta dr. ${ }^{1}$ - Milassin Ágnes dr. ${ }^{1}$ - Molnár Tamás dr. ${ }^{1}$ \\ 1Szegedi Tudományegyetem, Általános Orvostudományi Kar, I. Belgyógyászati Klinika, Szeged \\ ${ }^{2}$ Debreceni Tudományegyetem, Általános Orvostudományi Kar, II. Belgyógyászati Klinika, Debrecen \\ ${ }^{3}$ Markusovszky Egyetemi Oktatókórház, Szombathely \\ ${ }^{4}$ Semmelweis Egyetem, Általános Orvostudományi Kar, II. Belgyógyászati Klinika, Budapest \\ ${ }^{5}$ Petz Aladár Megyei Oktatókórház, Győr \\ ${ }^{6}$ Péterfy Sándor Utcai Kórház-Rendelőintézet és Sürgősségi Központ, Budapest \\ ${ }^{7}$ Pécsi Tudományegyetem, Általános Orvostudományi Kar, I. Belgyógyászati Klinika, Pécs \\ ${ }^{8}$ Semmelweis Kórház és Egyetemi Oktatókórház, Miskolc \\ ${ }^{9}$ Honvéd Kórház, Budapest \\ ${ }^{10}$ Kazincbarcikai Kórház, Kazincbarcika \\ ${ }^{11}$ Szegedi Tudományegyetem, Általános Orvostudományi Kar, Orvosi Fizika és Orvosi Informatika, Szeged
}

\begin{abstract}
Bevezetés: Európában 2012 óta engedélyezett adalimumab alkalmazása terápiarefrakter colitis ulcerosa kezelésére. Célkitüzés: A szerzők célja volt, hogy colitis ulcerosás betegek körében országos szinten felmérjék az adalimumab hatásosságát és biztonságosságát. Módszer: Prospektív tanulmányban felmérték a tartós klinikai válasz, a teljes remiszszió, illetve elsődleges vagy másodlagos hatásvesztés arányát a kezelés 12., 30. és 52 . hetében. Értékelték az 52 . héten a nyálkahártya-gyógyulás megoszlását. Eredmények: A vizsgálatba 73 aktív colitis ulcerosás beteget vontak be. Rövid távú klinikai válasz a betegek 75,3\%-ában alakult ki a 12. hétre. Az adalimumabkezelés fenntarthatóságának valószínúsége az 52 . hétig 48,6\% volt, amelyet tartós klinikai válasz kísért a betegek $92 \%$-ánál. Nyálkahártya-gyógyulás a betegek 48,1\%-ában volt kimutatható az 52 . héten. A betegek 17,6\%-ánál terápiamódosításra, 5,4\%-ánál colectomia elvégzésére került sor az egyéves időszak alatt. Következtetések: A colitis ulcerosa a kezdetektôl hatékony kezelést igényel, ezzel megelőzve a szövődményeket. Az eredmények alapján az adalimumab kedvező rövid és hosszú távú hatást mutat colitis ulcerosás betegeknél. Orv. Hetil., 2016, 157(18), 706-711.
\end{abstract}

Kulcsszavak: adalimumab, colitis ulcerosa, folyamatos klinikai válasz

\section{Long-term adalimumab therapy in ulcerative colitis in clinical practice: result of the Hungarian multicenter prospective study}

Introduction: Adalimumab was approved for the treatment of ulcerative colitis refractory to conventional therapy
several years later than infliximab in Europe. Due to the relatively low remission rate observed in Ultra trials, data on
the efficacy of adalimumab in ulcerative colitis are really helpful in the daily practice. Aim: The aim of this study was
to prospectively collect data on induction and maintenance adalimumab therapy in patients with ulcerative colitis
treated in Hungarian centres. Method: This prospective study collected data of all patients with ulcerative colitis
treated with adalimumab in 10 Hungarian centres. The primary endpoints of the study were rates of remission, re-
sponse and primary failure at week 12 , and the rate of continuous clinical response, remission and loss of response at
weeks 30, and 52 . Secondary endpoints were endoscopic outcome at week 52 and comparison of the efficacy of 
adalimumab between treatment naive and infliximab-experienced patients. Results: 73 patients with active ulcerative colitis were enrolled in the study. $75.3 \%$ of the patients exhibited clinical response after the induction at week 12 . The probability of maintaining adalimumab treatment was $48.6 \%$ at week 52 with a continuous clinical response in $92 \%$ of these patients. Mucosal healing was achieved in $48.1 \%$ of the patients at week 52 . Dose intensification was performed in $17.6 \%$ of the patients. Minor side effects developed in $4 \%$ of the patients and $5.4 \%$ of the patients underwent colectomy during the 1-year treatment period. Conclusions: These results coming from the real clinical setting demonstrate a favourable efficacy of adalimumab induction and maintenance therapy in patients with ulcerative colitis.

Keywords: ulcerative colitis, adalimumab, continuous clinical response

Rutka, M., Bálint, A., Farkas, K., Palatka, K., Lakner, L., Miheller, P., Rácz, I., Hegede, G., Vincze, Á., Horváth, G., Szabó, A., Nagy, F., Szepes, Z., Gábor, Z., Zsigmond, F., Zsóri, Á., Jubász, M., Csontos, Á., Szücs, M., Bor, R., Milassin, Á., Molnár, T. [Long-term adalimumab therapy in ulcerative colitis in clinical practice: result of the Hungarian multicenter prospective study]. Orv. Hetil., 2016, 157(18), 706-711.

(Beérkezett: 2016. február 19.; elfogadva: 2016. március 16.)

\section{Rövidítések}

$\mathrm{ADA}=$ adalimumab; $\mathrm{CRP}=(\mathrm{C}$-reactive protein $)$ C-reaktív protein; $\mathrm{EMEA}=($ European Medicine Agency $)$ Európai Gyógyszerügynökség; IFX = infliximab; pMayo score $=($ partial Mayo subscore) részleges Mayo-pontszám; $\mathrm{TB}=$ tuberculosis; $\mathrm{TNF}=$ tumornekrózis-factor; $\mathrm{UC}=$ colitis ulcerosa

A colitis ulcerosa (UC) krónikus autoimmun bélbetegség, amelyet változatos betegséglefolyás, relapsusos és remissziós időszakok váltakozása jellemez. Az esetek majdnem felében azonban krónikus aktivitással vagy gyakran relabáló jellegú betegségformával kell számolnunk [1], így a betegek gyakran szembesülhetnek kortikoszteroidkezelést igénylő relapsusokkal, amely a hospitalizáció és vastagbél-eltávolítás lehetőségét is magában hordozza. A súlyos szövődmények bekövetkezésének kockázata csökkenthető immunszuppresszív és/ vagy biológiai kezelés időben történő alkalmazásával. Az ACT tanulmány [2] eredményei alapján az infliximab(IFX-) kiméra monoklonális antitumornekrózis-faktor- $\alpha$ (anti-TNF- $\alpha$ ) antitest hatékony készítménynek bizonyult remisszió elérésére és fenntartására középsúlyos-súlyos UC esetén, 2006-ban pedig az EMEA (European Medicine Agency - Európiai Gyógyszerügynökség) jóváhagyta az UC kezelésére a fenti indikációkban. Mindamellett, hogy a tanulmányok és klinikai megfigyelések kedvező eredményeket szolgáltattak az IFX használatával kapcsolatban, felmerült az igény más készítmény alkalmazására is, amely nem kimératermészetû és nem intravénás adagolású. Miután két klinikai tanulmány is igazolta a teljesen humán $\mathrm{IgG}_{1}$ anti-TNF- $\alpha$ antitestet tartalmazó, szubkután adagolású adalimumab (ADA) hatékonyságát UC-ben, ez a készítmény is engedélyezést nyert az EMEA-tól 2012-ben [3,4], öt évvel később, mint Crohn-betegségben. Mivel gyakran ellentmondás mu- tatkozik a kutatási eredmények és a napi klinikai gyakorlat [5] között, továbbá szakértői vélemények szerint és az ULTRA tanulmány adatai alapján az ADA-kezelés hatékonysága alulértékelt UC-ben [6], a „real life” (való életből származó) adatok bemutatásának jelentős klinikai szerepe van. Jóllehet, 3 éve engedélyezett készítményről van szó, mégis viszonylag csekély számú napi gyakorlatból származó adat [7-10] látott napvilágot ez idő alatt, és ezen belül némelyik (inkább csak) retrospektív vizsgálat volt, viszonylag alacsony betegszámmal. Éppen ezért célul túztük ki, hogy multicentrikus, prospektív tanulmány keretén belül a forgalomba hozatali engedélyezést követően összegyújtjük az ADA-val kezelt magyarországi UC-betegek adatait a biológiai kezelésre jogosult egészségügyi központok bevonásával azért, hogy felmérjük az ADA rövid és hosszú távú hatékonyságát és biztonságosságát UC-ben.

\section{Módszer}

Az ADA rövid és hosszú távú hatékonyságának felmérése céljából prospektív vizsgálatot végeztünk 10 , gasztroenterológiai és gyulladásos bélbetegségek ellátására jogosult magyarországi centrum bevonásával 2013 és 2014 között. Felmérésünkbe a Mayo-pontrendszerrel igazolt klinikailag és endoszkóposan is aktív UC-s betegeket vontuk be. A demográfiai és klinikai adatokat egységes adatbázisban gyújtöttük. Rögzítésre kerültek a nemre, a betegség kiterjedésére és fennállására, az ADA indukciós és fenntartó dózisára és a dóziseszkalációra vonatkozó adatok. Információt gyújtöttünk a konkomittáló gyógyszeres kezelésre, a kezelés felfüggesztésének szükségességére, a megelóző IFX-terápiára vonatkozólag, valamint értékeltük az ADA-kezelésre adott klinikai válasz arányát a 12., 30. és 52. héten. Prospektíve vizsgáltuk a CRPszintek változását, a mellékhatások előfordulását, az eset- 
leges colectomia szükségességét, valamint az 52. hétre elért nyálkahártya-gyógyulás gyakoriságát.

A tanulmány elsődleges végpontjaként a 12 . héten értékeltük a klinikai válasz és remisszió, valamint a primer hatástalanság arányát, a 30 . és az 52 . héten a folyamatos klinikai válasz, remisszió és hatásvesztés százalékos megoszlását, valamint a tartósan ADA fenntartó kezelésen maradt betegek arányát az első év végére. A másodlagos végpontok között elemeztük az 52 . héten a nyálkahártya-gyógyulást mutató betegek megoszlását, valamint az ADA-kezelés hatékonyságát a biológiaiterápia-naiv és megelőzően IFX-kezelésben részesült betegek között.

A betegek klinikai állapotát a $0 ., 12 ., 30$. és 52 . héten mértük fel. Vastagbéltükrözés a kezelés megkezdése előtt és az 52 . héten történt. A vizsgálatunkba csak azokat a betegeket vontuk be, akiknél az endoszkópos Mayo-pontszám értéke legalább 2 volt. A klinikai remiszsziót a szteroidkezelés leállítása, valamint a parciális Mayo $\leq 2$ pont értéke jelentette úgy, hogy egyik önálló alpont sem haladta meg az l-et. Az ADA-kezelésre reagáló, úgynevezett reszponder betegeket a parciális Mayo 3 vagy annál több pontos csökkenésével definiáltuk. Folyamatos klinikai válaszként az 52 héten keresztül megtartott intermedier fellángolás nélküli klinikai válaszkészséget határoztuk meg. A nyálkahártya-gyógyulás megállapítására az endoszkópos Mayo 0 és 1 pontértékét fogadtuk el.

Az 52. héten értékelt mély remisszió definíciója alatt az endoszkópos és klinikai remisszió egyidejű fennállását értettük. A kategorikus adatok elemzésére a Pearson's $\chi^{2}$ vagy Fisher's egzakt tesztet használtuk. Az ismételt méréses varianciaanalízissel (ANOVA) vizsgáltuk a gyógyszeres kezelés hatását a CRP-re és a parciális Mayo-értékre. Kétmintás t-próbát használtunk az endoszkópos Mayo-pontok változásának értékelésére. A statisztikai teszteket az $\mathrm{R}$ statisztikai programmal végeztük ( $\mathrm{R}$ version 3.1.2), és 0,05 alatti p-értéket fogadtuk el szignifikáns eredménynek.

\section{Eredmények}

73, aktív UC-ben szenvedő beteget vontunk be prospektív, multicentrikus vizsgálatunkba. A betegek átlagéletkora a diagnózis idején 30,8 év (5-56 év) volt. 49 beteg $(67,1 \%)$ részesült korábban IFX-kezelésben. Az IFX-kezelés abbahagyása és ADA-ra történő váltása 10 beteg esetén $(20,4 \%)$ elsődleges hatástalanság, 18 beteg esetén $(36,7 \%)$ hatásvesztés, további 18 beteg esetén $(36,7 \%)$ pedig allergiás reakció jelentkezése, 3 betegnél $(6,1 \%)$ egyéb ok miatt történt. A bevonási időszakban a betegek 32,9\%-a részesült szteroid- és 52\%-a immunszuppresszív kezelésben. A betegek demográfiai és klinikai adatait az 1. táblázat foglalja össze. Az összes beteg - három beteg kivételével - (95,9\%) az indukciós kezelés során 160 mg készítményt kapott a 0 . héten, majd 80 mg-ot a második héten. Az ADA-kezelés megkezdésekor a pMayo átlaga 7,2 pont, az endoszkópos Mayo átlaga 2,7 pont, az átla-
1. táblázat |A vizsgálatba bevont betegek demográfiai és klinikai adatai

\begin{tabular}{|c|c|}
\hline Betegek száma (fő) & 73 \\
\hline Nem (férfi/nő) & $40 / 33$ \\
\hline Átlagos életkor a betegség kezdetén (év) & $30,8(5-56)$ \\
\hline Átlagos betegségfennállás (év) & $10,8(1-43)$ \\
\hline \multicolumn{2}{|l|}{ Betegségkiterjedés (fö) } \\
\hline Proctitis & 13 \\
\hline Bal oldali colitis & 14 \\
\hline Kiterjedt colitis & 46 \\
\hline Korábbi infliximabkezelés (fö) & 49 \\
\hline Szteroiddependens UC (fó) & 54 \\
\hline Szteroidrefrakter UC (fó) & 15 \\
\hline \multicolumn{2}{|l|}{ Konkomittáló kezelés (fő) } \\
\hline 5-ASA & 59 \\
\hline Kortikoszteroid & 24 \\
\hline Azatioprin & 38 \\
\hline ADA-dózis-intenzifikáció szükségessége (fő) & 13 \\
\hline Mellékhatás megjelenése (fó) & 3 \\
\hline Colectomia (db) & 5 \\
\hline Nyálkahártya-gyógyulás az 52 . héten (\%) & 48,1 \\
\hline
\end{tabular}

5-ASA = 5-acetilszalicilsav $; \mathrm{ADA}=$ adalimumab $; \mathrm{UC}=$ colitis ulcerosa

gos CRP-szint $15,7 \mathrm{mg} / 1$ volt. A 12 . hét végén, az indukciós kezelés befejezése után, az elsődleges hatástalanság aránya 24,7\%-nak, a klinikai választ és remissziót mutató betegek aránya pedig 49,3\%-nak és 26\%-nak bizonyult. A 30. hétre a betegek további 9,1\%-ánál volt megfigyelhető hatásveszés, a többi beteg között a klinikai válasz és a remisszió aránya pedig 34,1\%-nak és 56,8\%-nak bizonyult. Az 52. héten $8,3 \%$ volt a hatásvesztők, $33,3 \%$ a reszponderek és $58,3 \%$ a remisszióban levő betegek aránya. Az összes bevont beteg 45,2\%-a mutatott tartós klinikai választ 52 héten keresztül. A nem válaszoló, hatásvesztő, klinikai választ mutató és remisszióban lévő betegek arányát a 12., a 30. és az 52 . héten az 1. ábra foglalja össze. A 2. ábrán látható Kaplan-Meier-görbe az ADA-val kezelt betegek fellángolásmentes túlélését mutatja.

Az ADA-kezelés megkezdésének időpontjához viszonyítva a pMayo aktivitási index értéke és a CRP-szint szignifikánsan csökkent a 12. $(\mathrm{p}<0,001, \mathrm{p}<0,001)$, a 30. $(\mathrm{p}<0,001, \mathrm{p}<0,001)$ és az 52. $(\mathrm{p}<0,001, \mathrm{p}=0,03)$ hétre, habár további szignifikáns javulás nem volt kimutatható a klinikai aktivitás és CRP-szint tekintetében a 30. és 52. hétre a 12 . héthez képest.

A kezelési időszakban bekövetkezett pMayo-pontrendszer értékeit és a CRP-szint változásait a 3. ábra mu- 

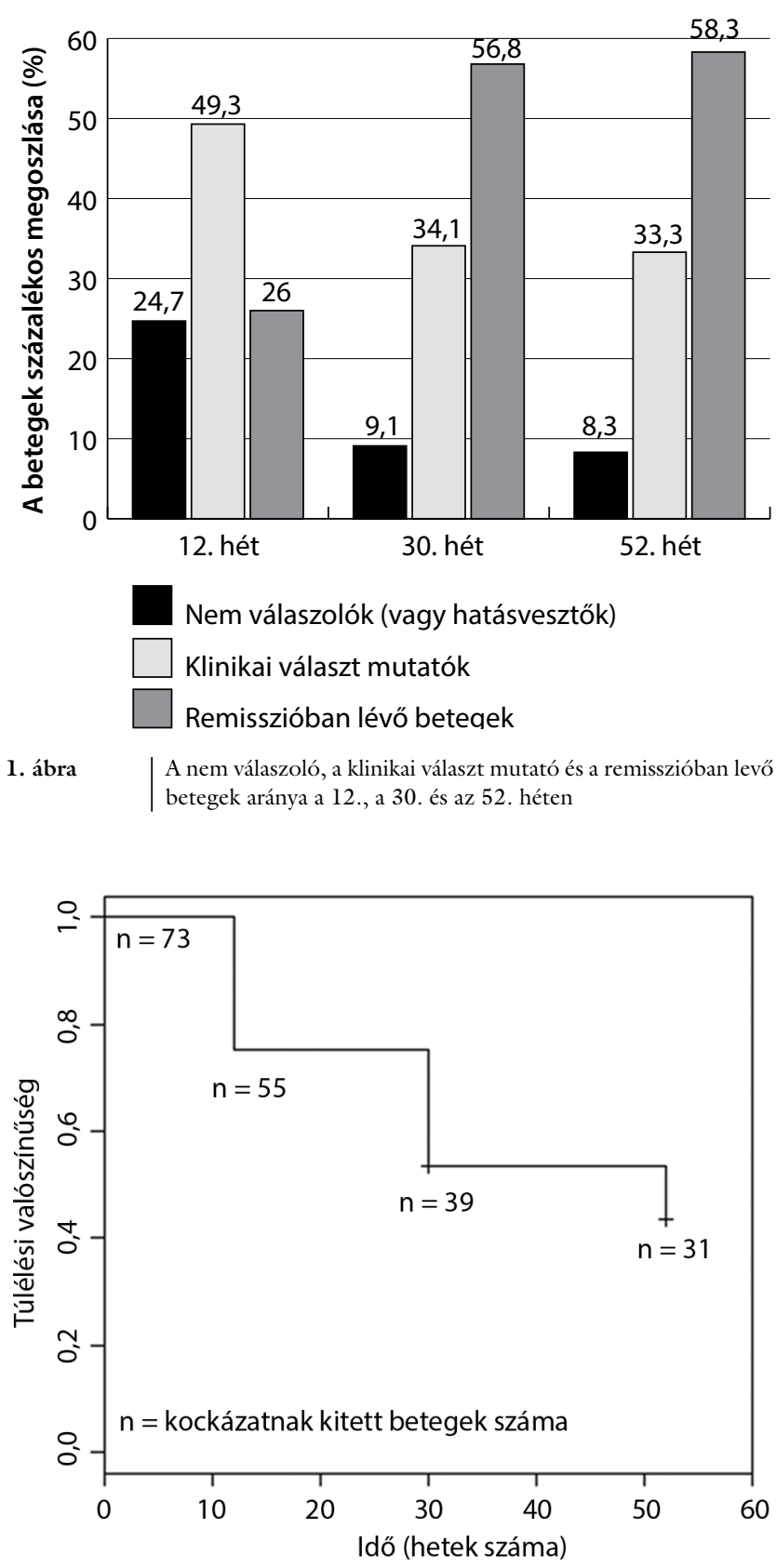

2. ábra

A Kaplan-Meier-görbe mutatja az ADA-kezelésben részesüló betegek fellángolásmentes túlélését

tatja be. A vizsgálat során 13 beteg esetében (17,8\%) történt dózissưrítés, 20 betegnél kellett leállítani az ADA-kezelést az egyéves terápiás időszak leforgása előtt (47,5\%-ban elsődleges hatástalanság, 17,5\%-ban hatásvesztés, 7,5\%-ban intolerancia, 35\%-ban beteg-együttmúködés hiánya miatt). Enyhe mellékhatás 3 betegnél alakult ki (bőrkiütés két betegnél, fáradtság és izomfájdalom egy betegnél) a teljes kezelési időszak alatt. Súlyos mellékhatás, tbc-fertőzés vagy daganatos megbetegedés nem fordult elő, azonban 5 beteg $(5,4 \%)$ esetében volt szükség colectomia elvégzésére. A megelőző IFX-kezelés nem mutatott összefüggést a betegség kimenetelével,

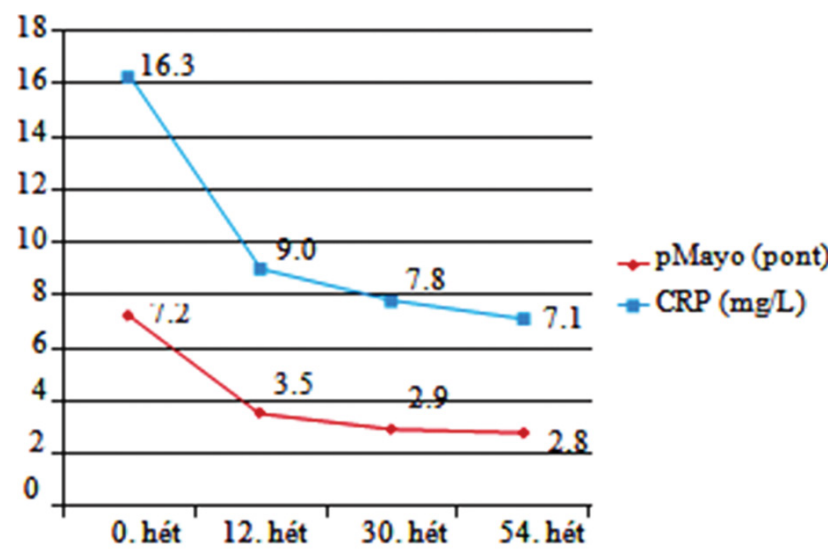

3. ábra $\quad$ A parciális Mayo (pMayo) -alpontszám és a C-reaktív protein (CRP) -szintek változása a 12., a 30. és az 52. héten

a dózissűrítés szükségességével vagy a mellékhatások kialakulásának gyakoriságával. A kolonoszkópos vizsgálat a 0 . héten 3 beteg kivételével minden esetben megtörtént, valamint az 52. héten 21 betegnél sikerült ellenőrző vastagbéltükrözést végezni. Az 52. hétre a vizsgált betegek 48,1\%-a ért el nyálkahártya-gyógyulást, ugyanekkor az átlagos endoszkópos Mayo-pontérték szignifikáns csökkenést $(2,6$ vs. 1,5, p<0,001) mutatott a kiinduláshoz viszonyítva. Komplett klinikai és endoszkópos remisszióban a betegek $55,6 \%$-a volt ebben az időpontban.

\section{Megbeszélés}

Prospektív, multicentrikus vizsgálatunkban az ADA-kezelés hatásosságát és biztonságosságát vizsgáltuk a klinikai gyakorlatban olyan aktív UC-s betegeknél, akiknél a hagyományos kezelés nem hozta meg a kívánt terápiás hatást. A bevont betegek kétharmada részesült korábban IFX-kezelésben, náluk az ADA-ra váltás javallatát leggyakrabban az IFX-kezelésre fellépő hatásvesztés, illetve allergiás reakció képezte. A betegek 75,3\%-a mutatott kedvező rövid távú klinikai választ a 12. hétre. Az ADAkezelés fenntarthatóságának valószínúsége az 52 . hétig 48,6\% volt, amelyet fenntartott klinikai válasz kísért a vizsgált csoport 92\%-ánál. Nyálkahártya-gyógyulás az endoszkópos vizsgálatok csaknem 50\%-ában volt kimutatható az 52. hétre. Dóziseszkaláció az esetek 17,8\%ában volt indokolt, enyhe mellékhatások kis arányban, a betegek 4,1\%-ában alakultak ki. A betegek 5,4\%-ánál colectomia elvégzésére került sor hatástalanság miatt az egyéves kezelési periódus alatt.

Az ULTRA-1 [3] és az ULTRA-2 [4] voltak azok az első randomizált, placebokontrollált klinikai tanulmányok, amelyek alátámasztották az ADA-kezelés hatásosságát UC-s betegeknél, azonban - nyilvánvaló, hogy a különböző módon megtervezett vizsgálatok nem alkalmasak az összehasonlításra - a terápiás hatékonyság feltû́nően elmaradt a korábbi IFX-kezeléssel foglalkozó felmérésben észleltekhez képest [2]. Az ULTRA-1 tanulmányban a betegek 16,9\%-ánál értek el szteroidmen- 
tes remissziót a 8 . hétre ADA-kezeléssel $160 \mathrm{mg} / 80$ $\mathrm{mg} / 40 \mathrm{mg}$ dózisban minden második héten adagolva (a placebocsoportban a betegek 9\%-ánál volt megfigyelhetó remisszió). Az ULTRA-2 tanulmányban szereplő 494, krónikusan aktív UC-s beteg részesült az ADA indukciós és fenntartó kezelésében, amelyet követôen klinikai választ az 52. héten a betegek 30,2\%-ában találtak, míg a placebokaron ez 18,3\% volt [3,4]. Bár az ADA-kezelés indikációs körének kibővítése és engedélyezése az UC kezelésére már három éve megtörtént, azonban továbbra is csak korlátozott számban állnak rendelkezésre adatok a mindennapi gyakorlatból. Mivel a kisszámú, klinikai gyakorlatból származó adatok többsége kedvezőbb hatékonyságot mutatott (igaz, kevesebb beteg bevonásával) az ULTRA tanulmányokhoz képest, továbbra is igény mutatkozik a szakma részéról az ADA hatékonyságát reálisan mutató, jól szervezett, minél több beteget vizsgáló klinikai tanulmányokra és átfogó közleményekre.

Armuzzi és mtsai 22, olaszországi egészségügyi centrumból származó adatokat közöltek UC-ben alkalmazott ADA-kezelés hatásosságáról. A klinikai remissziós arány $28,4 \%$-nak, 36,4\%-nak és $43,2 \%$-nak bizonyult a kezelés 12., 24. és 54 . hetében, valamivel alacsonyabb hatékonyságot mutatva a saját kutatási eredményeinkhez képest. Ugyanakkor a medián 11 hónapos követési idő után vastagbéltükrözésen átesett betegek 49,2\%-ánál figyeltek meg endoszkópos remissziót, továbbá 26,3\%-uk teljes nyálkahártya-gyógyulást ért el, ami majdnem megegyezik a saját eredményeinkkel [11].

Jóllehet, az anti-TNF- $\alpha$ hatóanyag elleni antitestképződést nem lehet teljes mértékben elkerülni, mégis nyilvánvaló, hogy a teljesen humán szerkezet miatt az ADA kevésbé immunogén, mint az IFX [12]. Ezért bír nagy jelentőséggel az ADA-kezelés hatékonyságának tanulmányozása azoknál a betegeknél, akik korábban az IFXkezelésre jól reagáltak, viszont a kezelés ideje alatt intolerancia alakult ki a szerrel szemben vagy hatásvesztés következett be.

Taxonera és mtsai az elsók közt tanulmányoztak olyan ADA-kezelésben részesülő UC-s betegeket, akik korábban IFX-kezelést kaptak. A kezelés 12. hetéig bezárólag klinikai választ az esetek 60\%-ában, klinikai remissziót az esetek 27\%-ában értek el [13]. Vizsgálatunkban megelőzően infliximabbal kezelt betegeink $42 \%$-a reagált folyamatos klinikai válasszal az alkalmazott ADA-kezelésre, emellett fontos kiemelni, hogy a korábbi IFX-kezelésnek nem volt hatása az ADA hatékonyságára, az ADA-dózissürítés szükségességére, illetve a mellékhatások gyakoriságára. Továbbá Taxonera és mtsai tanulmányában dóziseszkalációra a betegek 32,5\%-ánál, colectomiára a betegek $25 \%$-ánál volt szükség az ADA-kezelés elsődleges sikertelensége vagy másodlagos hatásvesztése miatt. Megfigyelték, hogy abban a betegcsoportban volt jelentôs a colectomia kockázata, amelyben a betegek nem reagáltak kedvezốen az ADA indukciós kezelésre a 12. hétig. Armuzzi és mtsai 5,5 hónapos medián követési idő alatt a betegek 35,2\%-ánál alkalmaztak dóziseszkalációt, és a betegek $25 \%$-ánál volt elkerülhetetlen a teljes vastagbél-eltávolítás elsődleges vagy másodlagos hatásvesztés következményeként. Mindkét tanulmány mérsékelten magasabb dóziseszkalációs és colectomiás arányt közölt vizsgálatunkhoz képest, azonban kiemelendő, hogy betegeink között a kombinált, immunszuppresszív szert is tartalmazó kezelés aránya jóval magasabb volt az előbb említett tanulmányokhoz képest.

Afif és mtsai közleményében az ADA-kezelésben részesülő betegeknél észlelt klinikai válasz, remisszió és nyálkahártya-gyógyulás aránya, jelen vizsgálatunkhoz hasonlóan, megegyezett az IFX-naiv betegek és megelözően IFX-szel kezelt betegek körében olyan esetekben, amikor a korábban alkalmazott IFX-terápia során hatásvesztés vagy intolerancia lépett fel [8]. Nemcsak a korábban alkalmazott IFX-kezelés ténye, hanem az arra adott válaszkészség is fontos szerepet játszhat az ADA-kezelés kimenetelének előrevetítésében. Ezzel összhangban, Garcia-Bosch és mtsai tanulmányában az egyetlen prediszponáló tényező az ADA-kezelés pozitív kimenetelére a korábbi IFX-re való kedvező klinikai válasz volt [14].

Vizsgálatunk fó korlátja, hogy nem értékeltük az immunogenitást az ADA-ellenes antitestszint mérésével. Mindazonáltal a klinikai gyakorlatban, fớként finanszírozási okokból, egyébként is ritkán történik meg az antiTNF- $\alpha$-szérumszint és az anti-TNF- $\alpha$-ellenes antitest meghatározása minden egyes kontrollvizsgálat alkalmával.

A klinikai gyakorlatból származó adatokat közlő vizsgálatok többsége nem használja a nyálkahártya-gyulladás értékelését az ADA-kezelés hatékonyságának felmérésére, noha az endoszkópia a legobjektívebb módszer a hatékonyság értékelésére. Az ULTRA-2 vizsgálatban a betegek 43\%-a ért el nyálkahártya-gyógyulást, Armuzzi és mtsai vizsgálatában a betegek $49 \%$-a, ami a jelen vizsgálatunkban kimutatott 48\%-os arányhoz hasonló.

Eredményeink összességében igazolták, hogy az ADA-kezelés kedvező hatású UC-ben is, még azoknál a betegeknél is, akik korábban IFX-kezelést kaptak, de hatásvesztés vagy allergia miatt terápiamódosításra volt szükség.

Anyagi támogatás: A közlemény megírása anyagi támogatásban nem részesült.

Szerzôi munkamegosztás: B. A., F. K., M. T.: Vizsgálati terv. R. M., Sz. M., B. A., F. K., M. T.: A kézirat megírása, statisztikai analízis, ábrák, táblázat készítése. B. A., F. K., P. K., L. L., M. P., R. I., Hegede G., V. Á., Horváth G., Sz. A., N. F., Sz. Z., G. Z., Zs. F., Zs. Á., J. M., Cs. Á., B. R., M. Á., R. M., M. T.: Betegválogatás, adatgyújtés, betegkövetés. M. T.: Betegválogatás és a kézirat ellenőrzése. A cikk végleges változatát valamennyi szerző elolvasta és jóváhagyta.

Érdekeltségek: A szerzőknek nincsenek érdekeltségeik. 


\section{Irodalom}

[1] Solberg, I. C., Lygren, I., Jahnsen, J., et al.: Clinical course during the first 10 years of ulcerative colitis: results from a populationbased inception cohort (IBSEN Study). Scand. J. Gastroenterol., $2009,44(4), 431-440$.

[2] Rutgeerts, P., Sandborn, W. J., Feagan, B. G., et al.: Infliximab for induction and maintenance therapy for ulcerative colitis. $\mathrm{N}$. Engl. J. Med., 2005, 353(23), 2462-2476.

[3] Reinisch, W., Sandborn, W. J., Hommes, D. W., et al.: Adalimumab for induction of clinical remission in moderately to severely active ulcerative colitis: results of a randomised controlled trial. Gut, 2011, 60(6), 780-787.

[4] Sandborn, W. J., van Assche, G., Reinisch, W., et al.: Adalimumab induces and maintains clinical remission in patients with moderate-to-severe ulcerative colitis. Gastroenterology, 2012, 142(2), 257-265.el-3.

[5] Levesque, B. G., Sandborn, W. J., Ruel, J., et al.: Converging goals of treatment of inflammatory bowel disease from clinical trials and practice. Gastroenterology, 2015, 148(1), 37-51.el.

[6] Kornbluth, A. A.: Adalimumab: another treatment option for moderate-to-severe UC. Gastroenterol. Hepatol. (N.Y.), 2013 , $9(5), 321$.

[7] Oussalah, A., Laclotte, C., Chevaux, J. B., et al.: Long-term outcome of adalimumab therapy for ulcerative colitis with intolerance or lost response to infliximab: a single-centre experience. Aliment. Pharmacol. Ther., 2008, 28(8), 966-972.

[8] Afif, W., Leighton, J. A., Hanawer, S. B., et al.: Open-label study of adalimumab in patients with ulcerative colitis including those with prior loss of response or intolerance to infliximab. Inflamm. Bowel Dis., 2009, 15(9), 1302-1307.
[9] Suzuki, Y., Motoya, S., Hanai, H., et al.: Efficacy and safety of adalimumab in Japanese patients with moderately to severely active ulcerative colitis. J. Gastroenterol., 2014, 49(2), 283-294.

[10] Gies, N., Kroeker, K. I., Wong, K., et al.: Treatment of ulcerative colitis with adalimumab or infliximab: long-term follow-up of a single-centre cohort. Aliment. Pharmacol. Ther., 2010, 32(4), 522-528.

[11] Armuzzi, A., Biancone, L., Daperno, M., et al.: Adalimumab in active ulcerative colitis: a "real-life" observational study. Dig. Liver Dis., 2013, 45(9), 738-743.

[12] Thomas, S. S., Borazan, N., Barroso, N., et al.: Comparative immunogenicity of TNF inhibitors: impact on clinical efficacy and tolerability in the management of autoimmune diseases. A systematic review and meta-analysis. BioDrugs, 2015, 29(4), 241258.

[13] Taxonera, C., Estellés, J., Fernández-Blanco, I., et al.: Adalimumab induction and maintenance therapy for patients with ulcerative colitis previously treated with infliximab. Aliment. Pharmacol. Ther., 2011, 33(3), 340-348.

[14] García-Bosch, O., Gisbert, J. P., Cañas-Ventura, A., et al.: Observational study on the efficacy of adalimumab for the treatment of ulcerative colitis and predictors of outcome. J. Crohns Colitis, 2013, 7(9), 717-722.

(Rutka Mariann dr., Szeged, Korányi fasor 8-10., 6720 e-mail: rutka.mariann@gmail.com)

\section{A rendezvények és kongresszusok híranyagának leadása}

a lap megjelenése elött legalább 40 nappal lehetséges, a 6 hetes nyomdai átfutás miatt. Kérjük megrendelőink szíves megértését.

A híranyagokat a következö címre kérjük: Orvosi Hetilap titkársága: Budai.Edit@akkrt.hu Akadémiai Kiadó Zrt. 